\begin{tabular}{c|l|l|l}
$\begin{array}{c}\text { Case Reports in } \\
\text { Oncology }\end{array}$ & $\begin{array}{l}\text { Case Rep Oncol 2010;3:439-444 } \\
\text { DOl: 10.1159/000322725 }\end{array}$ & $\begin{array}{l}\text { Published online: } \\
\text { November 29, 2010 }\end{array}$ & $\begin{array}{l}\text { O 2010 S. Karger AG, Basel } \\
\text { ISSN 1662-6575 } \\
\text { www.karger.com/cro }\end{array}$ \\
\hline
\end{tabular}

\title{
Diffuse Goiter and Severe Hypothyroidism due to Metastasis to the Thyroid
}

\author{
Anastasios Gkountouvas $^{\mathrm{a}} \quad$ Foteini Chatjimarkou $^{\mathrm{a}}$ \\ Maria Sevastiadou ${ }^{\mathrm{b}}$ Eleni Ntoula ${ }^{\mathrm{b}}$ Pavlos Georgiadis ${ }^{\mathrm{a}}$ \\ Philippos Kaldrimidis ${ }^{\mathrm{a}}$
}

Departments of aEndocrinology and Metabolism, and ${ }^{\mathrm{b} C y t o l o g y, ~ M e t a x a ~ C a n c e r ~}$

Hospital, Piraeus, Greece

\section{Key Words}

Esophageal adenocarcinoma · Goiter · Hypothyroidism · Metastatic lesions $\cdot$ Thyroid metastasis

\begin{abstract}
Despite the fact that the thyroid is a highly vascularized organ, clinically significant metastatic spread to the thyroid is considered uncommon. Hypothyroidism due to these metastases seldom occurs. A 68-year-old female patient came to our department because of rapid enlargement of the lower anterior part of the neck, which developed within 2 months. She had a history of poorly differentiated esophageal adenocarcinoma diagnosed 4 years ago, for which she underwent surgical removal of the neoplasm and received three cycles of chemotherapy. On physical examination, the clinical diagnosis was hypothyroidism with large, diffuse, firm goiter, and enlarged firm and fixed cervical lymph nodes. Thyroid and cervical ultrasound examination revealed significant diffuse enlargement of the thyroid, which was heterogeneous and hypoechogenic without focal lesions and multiple pathologically enlarged cervical lymph nodes. Laboratory examination revealed increased TSH levels with decreased free $T_{4}$ and $T_{3}$ levels. Fine needle aspiration biopsy of the thyroid revealed a metastatic adenocarcinoma. Our patient received external beam radiation therapy and chemotherapy, but unfortunately she passed away 4 months after diagnosis. Therefore, in case of a new (focal or diffuse) lesion in the thyroid gland in a patient with a history of malignant disease, regardless of the time elapsed since the diagnosis of the primary neoplasm, relapse of the preexisting disease must be considered until proven otherwise.
\end{abstract}




\begin{tabular}{|c|c|c|c|}
\hline $\begin{array}{c}\text { Case Reports in } \\
\text { Oncoloys }\end{array}$ & \begin{tabular}{|l|} 
Case Rep Oncol 2010;3:439-444 \\
DOI: $10.1159 / 000322725$
\end{tabular} & $\begin{array}{l}\text { Published online: } \\
\text { November 29, } 2010\end{array}$ & $\begin{array}{l}\text { O 2010 S. Karger AG, Basel } \\
\text { ISSN 1662-6575 } \\
\text { www.karger.com/cro }\end{array}$ \\
\hline
\end{tabular}

\section{Introduction}

Despite the fact that the thyroid is a highly vascularized organ, clinically significant metastatic spread to the thyroid is considered uncommon. Hypothyroidism due to these metastases seldom occurs.

Esophageal carcinoma is uncommon in the western world, but its prognosis is poor in the majority of patients, and mortality due to this neoplasm competes with mortality due to pancreatic carcinomas [1]. The thyroid gland is an unusual metastatic site for esophageal carcinoma [1]. We report a case of a female patient who developed severe hypothyroidism and diffuse goiter due to metastasis of her esophageal adenocarcinoma.

\section{Case Report}

A 68-year-old female patient came to our department because of a rapid enlargement in the anterior lower part of the neck, which developed within 2 months. She had a history of poorly differentiated esophageal adenocarcinoma diagnosed 4 years ago, for which she underwent surgical removal of the neoplasm and received chemotherapy without external beam radiotherapy (EBRT). Her follow-up for the esophageal adenocarcinoma did not reveal any relapse of the neoplasm until she was admitted to our department.

At presentation, she reported easy fatigability and weakness. On physical examination, she had rough, dry skin, hoarseness, a heart rate of 64 beats/min and a large, diffuse, firm goiter associated with enlarged firm and fixed cervical lymph nodes. Laboratory analysis revealed increased TSH levels (TSH $>50 \mathrm{mIU} / \mathrm{l}$, normal values $0.17-4.05 \mathrm{mIU} / \mathrm{l}$ ), decreased free $\mathrm{T}_{4}$ and $\mathrm{T}_{3}$ values (f $\mathrm{T}_{4}: 6.2 \mathrm{pmol} / \mathrm{l}$, normal values $11.5-23 \mathrm{pmol} / \mathrm{l} ; \mathrm{fT}_{3}: 0.9 \mathrm{pmol} / \mathrm{l}$, normal values $\left.2.5-5.8 \mathrm{pmol} / \mathrm{l}\right)$, increased anti-thyroid antibodies (anti-Tg: $>500 \mathrm{IU} / \mathrm{ml}$, normal values $<60 \mathrm{IU} / \mathrm{ml}$; anti-TPO: $>1,300 \mathrm{IU} / \mathrm{ml}$, normal values $<100 \mathrm{IU} / \mathrm{ml}$ ) and normal calcitonin levels (calcitonin: $0.1 \mathrm{pg} / \mathrm{ml}$, normal values $<10 \mathrm{pg} / \mathrm{ml}$ ). The tumor markers examined were within the normal limits. Her complete laboratory profile is outlined in table 1.

Thyroid and cervical ultrasound examination revealed significant diffuse enlargement of the thyroid with a heterogeneous and hypoechogenic pattern without focal lesions ( $\underline{\text { fig. }}$ 1, $\underline{\text { fig. }} \mathbf{2}$ ) and cervical lymphadenopathy. A CT of the neck indicated a diffuse neoplasm surrounding and infiltrating the trachea. A chest CT unveiled metastatic lesions in both lungs.

We performed fine needle aspiration biopsy (FNAB) of the thyroid (three passes in every lobe), and cytologically metastatic adenocarcinoma was found. Cytological samples did not unveil morphological characteristics of thyroid-derived malignant neoplasms (fig. 3). Immunostaining was negative for thyroglobulin, calcitonin, TTF1, K 5-6, CK20.

Surgical debulking was not possible, so EBRT of the neck and upper mediastinum was initiated with concomitant administration of docetaxel and cisplatin. After completion of radiotherapy (total dose: 3,900 cGy), six cycles of combination chemotherapy with irinotecan, oxaliplatin, 5-fluorouracil and folinic acid were scheduled at 28-day intervals. Two months after EBRT termination, neck CT disclosed a partial response of the thyroid lesion, but the abdominal CT unveiled a hepatic metastatic lesion that did not exist before treatment initiation. Unfortunately, her clinical condition aggravated despite an initial partial response to EBRT and she passed away due to her disease after the second cycle of chemotherapy (4 months after diagnosis).

\section{Discussion}

The incidence of metastatic disease to the thyroid ranged from 1.25 to $24 \%$ in previous studies $[2,3]$. Although the thyroid is a highly vascularized organ (being second after the adrenal gland), clinically significant metastases to the thyroid are uncommon [2-4]. Previously published studies on necrotic studies revealed that asymptomatic lesions are 


\begin{tabular}{c|l|l|l}
$\begin{array}{c}\text { Case Reports in } \\
\text { Olloloy }\end{array}$ & $\begin{array}{l}\text { Case Rep Oncol 2010;3:439-444 } \\
\text { DOI: 10.1159/000322725 }\end{array}$ & $\begin{array}{l}\text { Published online: } \\
\text { November 29, 2010 }\end{array}$ & $\begin{array}{l}\text { ISSN 1662-6575 } \\
\text { www.karger.com/cro }\end{array}$ \\
\hline
\end{tabular}

not unusual, as we assumed in the past, and they seem to occur more frequently than primary carcinomas of the gland $[2,5]$. Metastases to the thyroid frequently originate from the breast, lung and kidney. Several studies from autopsy series report that melanoma metastases are the most common, but these findings are not confirmed in clinical studies which indicate renal carcinomas to metastasize to the thyroid more frequently $[2,6,7]$.

Metastatic lesions to the thyroid may appear many years after diagnosis of the primary tumor. Especially in case of renal malignancy, previous reports indicated that metastatic disease may develop 27 years after the diagnosis of a primary neoplasm [2, 6-8]. Metastatic dissemination occurs mainly by hematogenous spread or infiltration of adjacent tissue $[8,9]$. Rarely, lymphatic or tumor-tumor dissemination may occur $[8,9]$.

Secondary lesions in the thyroid are usually solitary, while multifocal and diffuse lesions are rare. Thyroid function is not affected. Hypothyroidism due to metastases to the gland is uncommon and hyperthyroidism is even less frequent $[10,11]$. In our patient, hypothyroidism was present at diagnosis and she was referred to our department for suspect goiter, these findings being the early and only manifestations of her metastatic disease which finally proved to be widespread. In the literature, goiter and hypothyroidism were the manifestations of metastatic disease, but hypothyroidism occurred later in the course of the disease, with patients being euthyroid at goiter diagnosis $[12,13]$. We assume that, in our patient, massive invasion of the neoplasm led to severe hypothyroidism, probably due to preexisting, undiagnosed Hashimoto's thyroiditis and impaired thyroid reserve.

FNAB is an important tool in the diagnosis of metastatic disease. It is cheap and safe for the patient, and clinicians are able to define the nature of the neoplasm with accuracy [12-14]. Using FNAB, unnecessary thyroidectomy can be avoided in patients with a very poor prognosis $[2,13,14]$. The main limitation to the use of FNAB is that, sometimes, differential diagnosis between anaplastic thyroid carcinoma and metastatic lesions is difficult with this method [2]. Metastatic infiltration of the thyroid gland reflects a very poor prognosis (usually few months) because it appears in the context of widespread metastatic disease in most of the patients. However, in selected cases (mainly in metastases from renal carcinomas), surgical removal of solitary lesions may prolong survival $[2,6,8]$.

Conventional therapeutic approaches seem to be ineffective for the treatment of metastases to the thyroid gland [2]. Although treatment must be individualized, aggressive surgical removal of metastases, where necessary and possible, and EBRT are the main therapeutic choices $[2,3,15]$.

In conclusion, every new - focal or diffuse - lesion to the thyroid gland in a patient with a history of malignant disease, regardless of the time elapsed from the diagnosis of the primary neoplasm, must be considered as relapse of the preexisting disease until proven otherwise [2]. Also, in our opinion, metastatic disease to the thyroid must be borne in mind in the differential diagnosis of hypothyroidism in patients with known malignant disease. 


\section{Conflict of Interest}

The authors have no financial conflicts of interest.

Table 1. Laboratory profile of the patient at diagnosis

\begin{tabular}{lcc}
\hline Parameters & Patient & Normal range \\
\hline WBC, $\mathrm{n} / \mu \mathrm{l}$ & 13,900 & $4,000-11,000$ \\
Neutrophils, $\mathrm{n} / \mu \mathrm{l}$ & 10,370 & $2,500-7,500$ \\
Lymphocytes, $\mathrm{n} / \mu \mathrm{l}$ & 1,970 & $1,500-3,500$ \\
Hemoglobin, g/dl & 13 & $11.5-15.5$ \\
Platelets, $\mathrm{n} / \mu \mathrm{l}$ & 667,000 & $150,000-400,000$ \\
Urea, mg/dl & 27 & $15-40$ \\
Creatinine, mg/dl & 0.9 & $0.6-1.1$ \\
SGOT, U/l & 18 & $10-40$ \\
SGPT, U/l & 8 & $10-35$ \\
$\gamma$ GT, U/l & 12 & $<30$ \\
Alkaline phosphatase, U/l & 75 & $40-150$ \\
Bilirubin (total), mg/dl & 0.4 & $0.2-1$ \\
LDH, U/l & 243 & $125-245$ \\
Na, mmol/l & 141 & $136-145$ \\
K, mmol/l & 4.4 & $3.5-5.1$ \\
Ca, mg/dl & 8.9 & $8.4-10.2$ \\
P, mg/dl & 3.6 & $2.7-4.5$ \\
Albumin, g/dl & 4.4 & $3.5-5$ \\
Cholesterol, mg/dl & 258 & $<200$ \\
LDL cholesterol & 175.6 & $<130$ \\
HDL cholesterol & 63 & $>40$ \\
Triglycerides & 97 & $<150$ \\
CPK, U/l & 166 & $38-174$ \\
fT, pmol/l & 6.2 & $11.5-23$ \\
fT, pmol/l & 0.9 & $2.5-5.8$ \\
TSH, mIU/l & $>50$ & $0.17-4.05$ \\
Anti-TG, IU/ml & $<60$ \\
Anti-TPO, IU/ml & 0.1 & $<100$ \\
Calcitonin, pg/ml & 300 & \\
\hline & & \\
& &
\end{tabular}




\begin{tabular}{c|l|l|l}
$\begin{array}{c}\text { Case Reports in } \\
\text { Oncology }\end{array}$ & $\begin{array}{l}\text { Case Rep Oncol 2010;3:439-444 } \\
\text { DOI: 10.1159/000322725 }\end{array}$ & $\begin{array}{l}\text { Published online: } \\
\text { November 29, 2010 }\end{array}$ & $\begin{array}{l}\text { O 2010 S. Karger AG, Basel } \\
\text { ISSN 1662-6575 } \\
\text { www.karger.com/cro }\end{array}$ \\
\hline
\end{tabular}

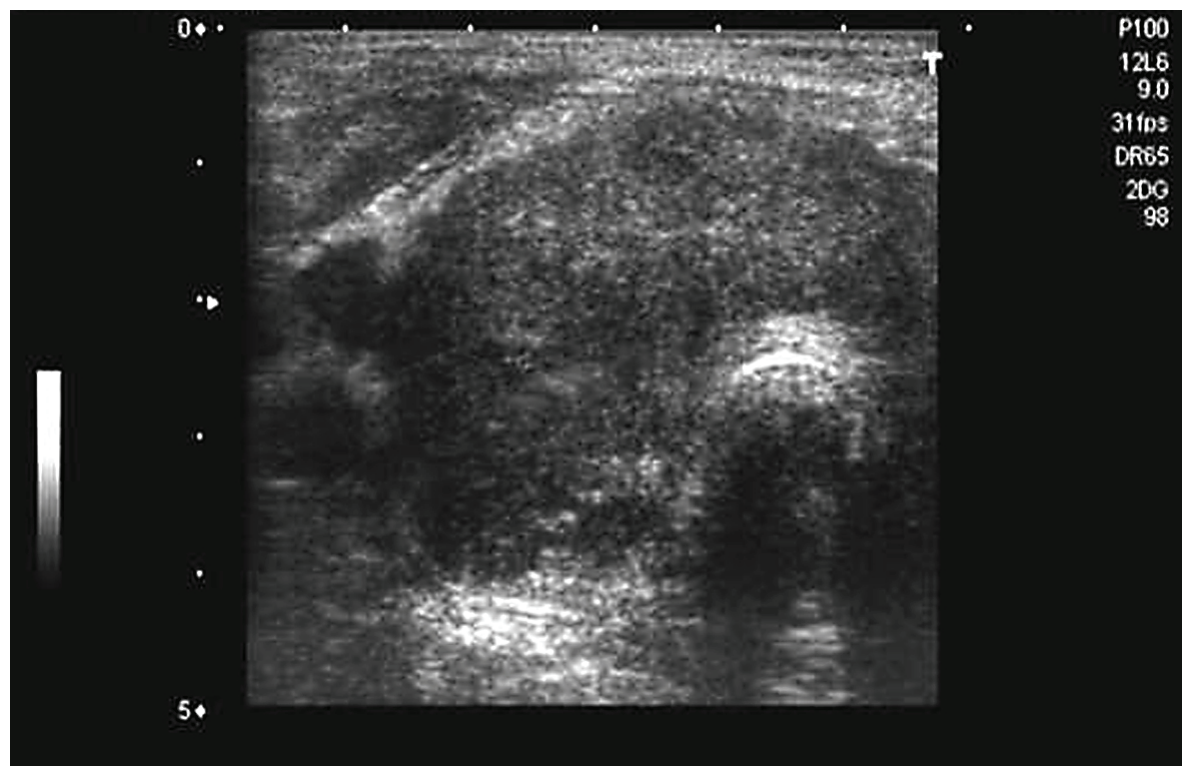

Fig. 1. Ultrasonography of the right thyroid lobe.

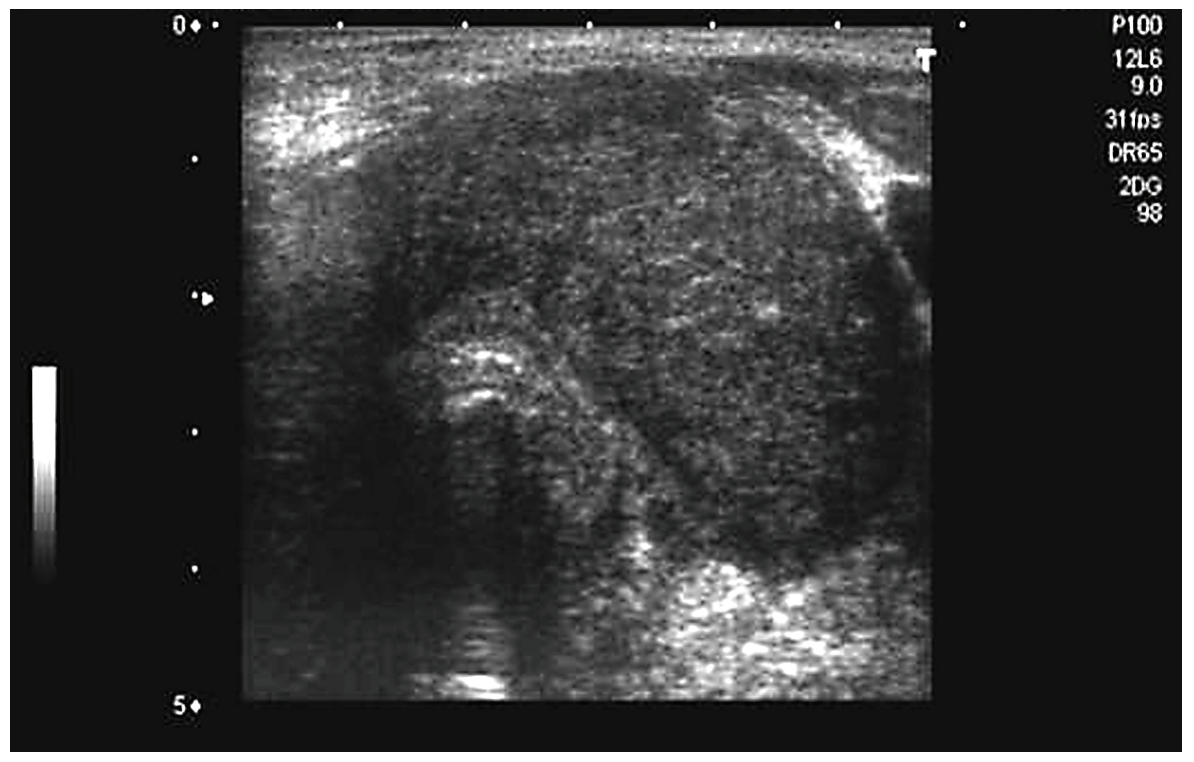

Fig. 2. Ultrasonography of the left thyroid lobe. 


\begin{tabular}{|c|c|c|c|}
\hline $\begin{array}{l}\text { Case Reports in } \\
\text { Oncoloys }\end{array}$ & $\begin{array}{l}\text { Case Rep Oncol 2010;3:439-444 } \\
\text { DOI: } 10.1159 / 000322725\end{array}$ & $\begin{array}{l}\text { Published online: } \\
\text { November 29, } 2010\end{array}$ & \begin{tabular}{|l} 
@ 2010 S. Karger AG, Basel \\
ISSN 1662-6575 \\
www.karger.com/cro
\end{tabular} \\
\hline
\end{tabular}

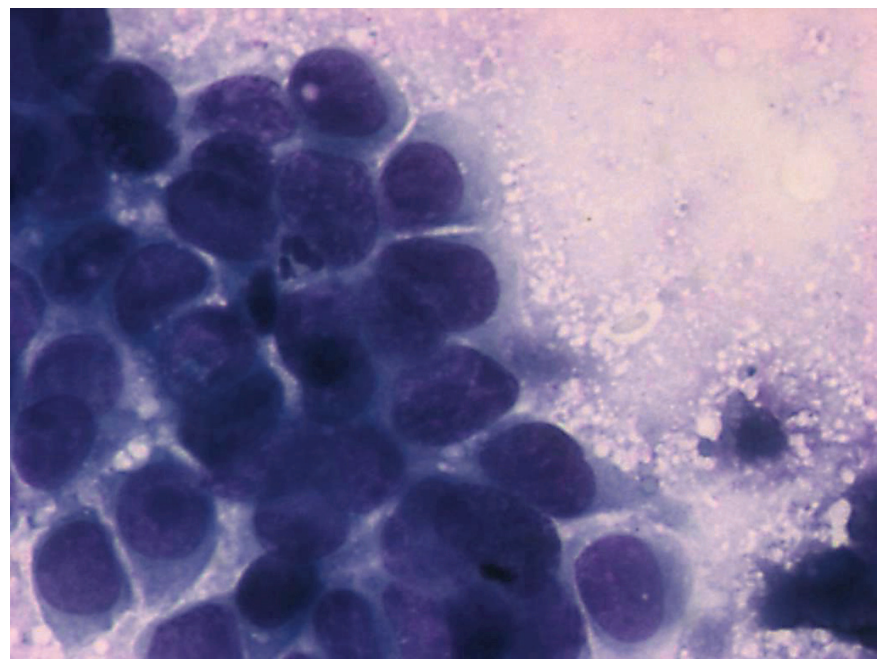

Fig. 3. Cytologic samples from our patient's FNAB (Giemsa stain) without morphologic characteristics of thyroid-derived carcinoma.

\section{References}

1 Paz BI, Hwang JJ, Iyer R, Coia L: Esophageal cancer; in Cancer Management Handbook 2005-2006. http://www.cancernetwork.com/oncology/.

2 Nakhjavani MK, Gharib H, Goellner JR, Van Heerden JA: Metastasis to the thyroid gland. A report of 43 cases. Cancer 1997;79:754-758.

-3 Cumbo-Nacheli G, De Sanctis JT, Chung MH: Proximal esophageal adenocarcinoma presenting as a thyroid mass: case report and review of the literature. Thyroid 2007;17:267-269.

4 Wychulis AR, Beahrs OH, Woolner LB: Metastasis of carcinoma to the thyroid gland. Ann Surg 1964;160:169177.

5 Shimaoka K, Sokal JE, Pickren JW: Metastatic neoplasms in the thyroid gland. Cancer 1962;15:557-565.

-6 Green LK, Ro JY, Mackay B, Ayala AG, Luna MA: Renal cell carcinoma metastatic to the thyroid. Cancer 1989;63:1810-1815.

7 Lam KY, Lo CY: Metastatic tumors of the thyroid gland. A study of 79 cases in Chinese patients. Arch Pathol Lab Med 1998;122:37-41.

8 Basu S, Nair N, Borges AM: Squamous cell carcinoma of esophagus masquerading as solitary thyroid nodule. Indian J Cancer 2005;42:205-207.

9 Shomaf MS: Tumor-to-tumor metastasis to follicular adenoma of thyroid: case report and review of the literature. Ann Saudi Med 2002;22:224-225.

10 Bandyopadhyay SK, Bandyopadhyay R, Dutta A: Isolated massive thyroid metastasis in lung cancer. Singapore Med J 2006;47:324-326.

11 Miyakawa M, Sato K, Hasegawa M, Nagai A, Sawada T, Tsushima T, et al: Severe thyrotoxicosis induced by thyroid metastasis of lung adenocarcinoma: a case report and review of the literature. Thyroid 2001;11:883888.

12 Bae WK, Shim HJ, Choi YD, Kim JW, Cho SH, Kang HC, et al: Severe hypothyroidism induced by thyroid metastasis of cholangiocarcinoma. Cancer Res Treat 2009;41:56-58.

-13 Youn JC, Rhee Y, Park SY, Kim WH, Kim SJ, Chung HC, et al: Severe hypothyroidism induced by thyroid metastasis of colon adenocarcinoma: a case report and review of the literature. Endocr J 2006;53:339-343.

14 Watts NB: Carcinoma metastatic to the thyroid: prevalence and diagnosis by fine-needle aspiration cytology. Am J Med Sci 1987;293:13-17.

15 Kim TY, Kim WB, Gong G, Hong SJ, Shong YK: Metastasis to the thyroid diagnosed by fine-needle aspiration biopsy. Clin Endocrinol (Oxf) 2005;62:236-241. 